\title{
Godność osoby umierającej powinnością moralną w medycynie*
}

\author{
Justyna Czekajewska \\ Katedra Nauk Społecznych i Humanistycznych, Wydział Nauk o Zdrowiu \\ Uniwersytet Medyczny im. Karola Marcinkowskiego w Poznaniu, ul. Rokietnicka 7, 60-806 Poznań \\ justynaczekajewska@gmail.com
}

\section{Streszczenie}

W tradycji chrześcijańskiej pojęcie „godności” wynika z prawa naturalnego. Według św. Tomasza z Akwinu każdy człowiek zachowuje swoją przyrodzoną godność, ponieważ pochodzi ona od Boga. Adekwatny z tą myślą jest pogląd, że dar godności nie można nikomu odebrać. Nawet różne formy przejawu agresji i nienawiści nie są w stanie unicestwić człowieczeństwa, innymi słowy nie mogą one pozbawićc cłłowieka tej najcenniejszej wartości.

W trosce o rozwój duchowy filozofowie i teolodzy nakłaniają do postępowania zgodnie z moralnymi standardami. Czyny oparte na etycznym fundamencie uczą odpowiedzialności, dlatego są tak ważne, aby je przestrzegać.

W artykule temat godności człowieka uzasadniam na przykładzie opieki medycznej nad pacjentem chorym chronicznie i terminalnie. W pracy nie tylko przedstawiam najważniejsze założenia opieki paliatywnej, ale także wyjaśniam w jaki sposób można troszczyć się o osobę umierająca, respektując przy tym jej prawa jako pacjenta, a szczególnie prawo do godnej i spokojnej śmierci.

\section{Słowa klucze}

godność, opieka paliatywna, godna śmierć, edukacja tanatologiczna, uśmierzenie bólu, choroba nowotworowa

\section{Znaczenie godności w teologii i filozofii - wprowadzenie}

W historii ludzkości pojęcie „godności” zawsze odgrywało ważne znaczenie. W tra-

\footnotetext{
* Artykuł ten stanowi odwołanie do wykładu otwartego, który został wygłoszony przez autorkę tekstu podczas inauguracji zajęć dydaktycznych w roku akademickim 2016/2017 dla uczniów LO objętych patronatem przez J. M. Rektora UMP, Prof. dr hab. Andrzeja Tykarskiego (29 XI 2016). Zob. (Web-01)

1 Godność człowieka - łac. dignitas hominis. Wewnętrzna właściwość osoby ludzkiej, która zawiera się w sposób konieczny w jej strukturze bytowej i przez którą osoba ludzka istnieje jako cel, nie jako środek działania.
}

dycji Zachodniej, której korzenie pochodzą z hebrajskiej koncepcji stworzenia świata w szczególny sposób traktuje się wartość życia. „Zgodnie z treścią nauczania Magisterium Kościoła, świętość każdego istnienia ludzkiego jest prawem absolutnym, zasadą ogólną niepodważalną przez jakąkolwiek racje moralną" ${ }^{2}$. Teistyczny wymiar natury człowieka wynika z prawa moralnego

2 „Stworzenie człowieka [przez Boga] jest ukoronowaniem całego dzieła stworzenia. Będąc stworzonym na obraz Boga, człowiek może prowadzić z Bogiem dialog [...]. Człowiek jest panem ziemi, jest on uosobieniem Bożej obecności na ziemi [dlatego święte jest jego życie]”. Zob. (Dufour 1990: 184-185). Por. (Czekajewska 2014: s. 69-70). 
objawionego przez Boga. Oznacza to, że wszystko co zostało napisane o Bogu i człowieku w Piśmie Świętym nie może zostać podważone przez prawo ustawowe danego kraju. Jego unieważnienie oznaczałoby zlekceważenie naturalnego prawa moralnego, które wiążę człowieka z Bogiem.

W epoce średniowiecza spośród wszystkich teologów, to św. Tomasz z Akwinu udoskonalił koncepcję prawa moralnego naturalnego. Ograniczył on prawo naturalne do natury człowieka, argumentując, że każde życie ludzkie pochodzi od Boga, dlatego byt osoby człowieka jest stałym punktem rozważań, zwornikiem wszelkiego istnienia, czyli podstawą i kluczem metodologii, hermeneutyki oraz epistemologii.

Zdaniem św. Tomasza z Akwinu przedstawiony w Piśmie Świętym opis stworzenia świata, wyraża wolę Stwórcy. Oznacza to, że wszechświat nie jest chaosem, ale uporządkowaną materią, która zakłada pewną teleologię. Celowość jest prawem panującym nad wszelkim istnieniem nad każdą cząstką nawet najmniejszą. Człowiek, który w stworzonym porządku istnienia zajmuje centralne miejsce, nie jest pozbawiony opieki Absolutu. Jak każdy element tego świata podlega on prawom, choć jego natura wyróżnia go spośród wszelkiego stworzenia. Podmiot osobowy jest szczególny ze względu na obecność w nim przeciwstawnych pierwiastków: cielesnego i duchowego ${ }^{3}$. Bóg w swej sprawczej mocy obdarował człowieka niezdeterminowaną wolą, która upodabnia go do Stworzyciela. Ofiarowane atrybuty rozumu i wolnej woli są właściwe tylko człowiekowi, dlatego podlega on prawu wyboru. Może on artykułować swoje przekonania, sprzeciwiać się, kiedy inni nie respektują jego podmiotowej natury i traktują go instrumentalnie, a także czynić dobro oraz kierować się współczuciem. Moc

3 „Zdanie dusza jest człowiekiem można rozumieć w dwojaki sposób; najpierw tak: Człowiek ogólnie wzięty jest duszą; natomiast ten oto człowiek, np. Sokrates, nie jest duszą, ale jestestwem złożonym z duszy i ciała”. (Tomasz z Akwinu 1960: 12) jego woli może uczynić więcej od innych stworzeń, które pozbawione władzy sądzenia, ulegają sile instynktu ${ }^{4}$. Skoro podmiot ludzki jest wolny, jest również obdarzony możliwością wyboru, sui iuris - podejmujący decyzję, a więc odpowiedzialny za skutki swojego działania.

Wraz z upływem wieków przekonanie Akwinaty o cielesno-duchowej strukturze podmiotu ludzkiego doczekało się kontynuacji. Ważni przywódcy Kościoła rzymsko-katolickiego jak: Jan Paweł II czy Benedykt XVI w różnych dziełach - encyklikach, adhortacjach takich jak: Redemptor hominis, Evangelium vitae czy Dignitas Personae, argumentowali, że osoba jako podmiot jest ontycznie integralna w so$b e^{5}$. Integralna oznacza całość elementów,

4 Informacje przedstawione w artykule na temat zdolności poznawczych zwierząt wynikają z treści dokumentów Kościoła. Chcę podkreślić, że istnieją naukowe opracowania, które ten temat przedstawiają szerzej. Ostatnie badania przeprowadzone przez Petera Wohllebena dowodzą, że niektóre gatunki zwierząt posiadają w dużym stopniu rozwiniętą zdolność do duchowej refleksji. "Nauka chcąc sprawdzić, czy zwierzęta posiadają zdolność [samoświadomości], wymyśliła test lustra. Kto potrafi rozpoznać, że obraz w lustrze nie jest pobratymcem tego samego gatunku, lecz stanowi odbicie własnej postaci, ten powinien być wstanie dokonać refleksji nad sobą. [...]. Od tej pory uważa się ten test za dowód istnienia samoświadomości u zwierząt, które go zdały. Radzą z nim sobie małpy człekokształtne, delfiny i słonie, które zdecydowanie zyskały odtąd w opinii uczonych". Zob. (Wohlleben 2017: 158-159).

5 „Godność osobowa stanowi podstawę równości wszystkich ludzi, (...) jest niezniszczalną własnością każdej ludzkiej istoty. (...) Wynika z tego, że jednostki absolutnie nie można sprowadzić do tego, co mogłoby ją zmiażdżyć i unicestwić w anonimowości kolektywu, instytucji, struktury czy systemu". (Jan Paweł II 1989: 123) „Tracąc wrażliwość na Boga traci się wrażliwość na drugiego człowieka, jego godność i życie”. Por. (Jan Paweł II 1995: 21) „Każdej istocie ludzkiej, od poczęcia aż po naturalną śmierć, należy się godność osoby. Ta podstawowa zasada, wyrażająca wielkie „tak” dla ludzkiego życia, powinna znaleźć się w centrum refleksji etycznej nad badaniami naukowymi w dziedzinie biomedycyny, które w dzisiejszym świecie nabierają coraz większego znaczenia”. (Kongregacja Nauki Wiary 2008). 
łącznie ze strukturą psychiczną, biologiczną oraz relacją do społeczeństwa. Tak przedstawiony podmiot obejmuje wszystkie warstwy bytu ludzkiego, tworząc koherentną i niepowtarzalną całość. Dzięki naturze jesteśmy wyposażeni w pewne zdolności pozwalające nam działać jako osobie ludzkiej.

W ten oto sposób od wieków kształtowały się poglądy dotyczące natury człowieka, godności osobowej, a wraz z nią człowieczeństwa. Wielu etycznych personalistów takich jak: Tadeusz Styczeń, Adam Rodziński, czy Marek Piechowiak, korzystali z osiągnięć wymienionych filozofów i teologów, po to, żeby również wyrazić przekonanie, że osobie jako osobie należna jest afirmacja (szacunek, miłość) dla niej samej. Rozpoznanie siebie jako wartości przynależne jest tylko człowiekowi. Ktoś kto nie może poznawać, nie może też dostrzegać i rozumieć wartości. Proces hominizacji akcentuje absolutną tajemnicę istnienia poprzez aktywność i doskonalenie natury ludzkiej.

\section{Odróżnienie godności osobowej od godności osobistej człowieka}

Pojęcie godności osobowej, które ma wielowiekowe tradycje nie może zawężać obszaru filozoficznych rozważań. Oznacza, to, że termin "godność” nie ma jednego znaczenia. Inaczej mówiąc, nie jest on wyłącznie zarezerwowany dla teorii etycznego personalizmu, w której zawarta jest myśl, że życie każdego człowieka jest cenne, ponieważ życie samo w sobie jest wartością przyrodzoną i niezbywalną. Poza rozumieniem godności osobowej istnieje także jej drugi rodzaj, który odnosi się do godnego zachowania i godnej postawy. Godność osobista związana jest z postępowaniem moralnym człowieka i w zależności od naszych czynów można ją nabywać lub utracić, a działania innych ludzi mogą przyczyniać się do jej rozwoju lub ją utrudniać.

Wybitne osobistości: filozofowie, pedagodzy, lekarze oraz teoretycy prawa i doktryn politycznych np. John Locke ${ }^{6}$, Immanuel Kant ${ }^{7}$, Maria Ossowska, Janusz Korczak ${ }^{8}$, czy Martin Luther King ${ }^{9}$, uważali, że liczne przykłady nieszanowania życia ludzkiego w wyniku stosowania tortur, niewolnictwa, przeprowadzania eksperymentów medycznych, a także głoszenia nienawiści na tle rasowym atakują wartość człowieczeństwa, chcąc ją unicestwić. Stąd też pojawiła się propozycja wprowadzenia praw, które będą chronić godności osób pokrzywdzonych, ale także ją odbierać tym, którzy na to zasługują. Utracić godność można poprzez stosowanie sankcji, a szczególnie znane są przykłady utraty praw obywatelskich, honoru, kary więzienia, a w niektórych państwach i stanach Ameryki kary śmierci.

Rozważania uczonych na temat szacunku dla godności człowieka przyczyniły się do zmiany dyskursu z teologicznego na jurydyczny. Uznano, że wprowadzenie międzynarodowych dyrektyw nałoży obowiązek przestrzegania zasad takich jak: prawo do życia, wolności oraz godności. Nie tylko twórcy Deklaracji Niepodległości uznali te zmiany za bardzo cenne. W późniejszym okresie (po wydarzeniach z I i II wojny światowej) 10 grudnia 1948r. została uchwalona Powszechna Deklaracja Praw Człowieka i artykuł 1 tego dokumentu zawiera następująca

6 „Istnieją pewne określone „naturalne” prawa, które są uniwersalne i absolutne - takie jak prawo do życia, wolności i własności". J. Locke w oparciu o prawo natury ludzkiej uważał, że każdy człowiek posiada niezbywalne prawo do własności i wolności i na tej zasadzie zostały sformułowane postulaty polityczne, które dały początek Deklaracji Niepodległości. (Locke 2015).

7 „Postępuj tak byś człowieczeństwa tak w twej osobie, jako też w osobie każdego innego używał zawsze zarazem jako celu, nigdy tylko jako środka". (Kant 1984: 62).

8 "Jestem nie po to aby mnie kochali i podziwiali, ale po to abym ja działam i kochał. Nie jest obowiązkiem otoczenia pomagać mnie, ale ja mam obowiązek troszczenia się o świat, o człowieka”. (Korczak 2012: 84).

9 „Nauczyliśmy się fruwać niczym ptaki na niebie, pływać niczym ryby w morzach, ale nie nauczyliśmy się tej prostej sztuki, by żyć ze sobą jak bracia”. (King 1977). 
zasadę: „Wszyscy ludzie rodzą się wolni i równi pod względem swej godności i swych praw. Są oni obdarzeni rozumem i sumieniem oraz powinni postępować w stosunku do siebie wzajemnie w duchu braterstwa”.

Wprowadzenie międzynarodowych ustaw nie tylko zobowiązało mieszkańców różnych państw ONZ do ich przestrzegania, ale również dało początek formowania innych praw np. praw kobiet, praw dziecka, a także praw pacjenta.

\section{Systemowy model opieki rodziny nad osobą umierającą}

W karcie praw pacjenta (już na samym początku) w pkt. 4 i 5 pojawia się sformułowanie praw: „prawa do intymności i poszanowania godności osobistej w czasie udzielania świadczeń zdrowotnych oraz prawa do umierania w spokoju i godności" (Dz.U. 2009 nr 52 poz. 417: art. 19, p. 4, art 39, p. 5). Wskazane dwie zasady przypominają, że choroba nie może być powodem dla instrumentalnego traktowania drugiego człowieka. Nawet jeśli opieka medyczna dotyczy pacjenta chronicznie i terminalnie chorego, to nie można unieważnić jego człowieczeństwa np. przez ignorowanie podstawowych potrzeb, wyśmiewanie, uniemożliwianie kontaktu z osobami bliskimi czy kapłanem oraz stosowanie uporczywej terapii i metod nieproporcjonalnych (nadzwyczajnych).

Wskazane przykłady instrumentalnego traktowania pacjenta, powinny być przestrogą nie tylko dla pracowników służby zdrowia (lekarzy, pielęgniarek, laborantów medycznych), ale także członków rodziny oraz wolontariuszy.

Opieka nad osobą umierającą jest bardzo trudna. Niezależnie kto jest pacjentem (dorosły, czy dziecko), to świadomość zbliżającej się śmierci zawsze budzi silne i negatywne doznania. Rodzinom niezmiernie rzadko udaje się natychmiast wypracować konstruktywny model relacji. Pierwszą przeszkodą na drodze do jej osiągnięcia jest zamknięta postawa chorego. Może on albo odrzucać prawdę, nie akceptować jej, wypierać z własnej świadomości i zaprzeczać wynikom dostarczonych badań, bądź też przyjąć postawę buntu, uznać, że wszystko co go spotyka jest niesprawiedliwe. Pacjent chorobę traktuje więc jako krzywdę lub zagrożenie (Góralczyk 1996: 17) ${ }^{10}$. Po drugie, jeśli pacjentem jest dziecko, to w takiej sytuacji również rodzice przejawiają taką samą postawę. Przeważnie szukają oni winnego i mają pretensje do otoczenia oto co ich spotkało. Nierzadko też poświęcają oni jeszcze więcej uwagi osobie chorej niż pozostałym, zdrowym dzieciom, wykazując tendencje nadopiekuńcze, które nie tylko sprawiają, że inne dzieci czują się niezauważane, pominięte, ale także sam chory nie ma przez to przestrzeni potrzebnej do zabawy, swobodnego kontaktu z rodzeństwem i z przyjaciółmi (Gizicka 2010: 325).

Choroba terminalna pacjenta często zmienia nie tylko jego bieg życia codziennego, ale także wszystkich członków rodziny. Jeśli relacje między chorym, a rodziną będą przypominać „zaklęty krąg”, to każda jednostka będzie mieć wpływ na pozostałych domowników zmuszając ich do reakcji przystosowawczej (Leone 2000: 16). W tym modelu kołowym choroba zaczyna skutecznie niszczyć całą rodzinę, ponieważ każdy ma pretensje do drugiej osoby. Chory dlatego, że nie zastosowano odpowiedniego leczenia, które zapewniłoby powrót do zdrowia, rodzice, którzy przejawiają postawę nadopiekuńczą również nie mają czasu dla siebie i na wypoczynek, a dzieci dlatego, że czują się zaniedbywane.

10 Por. (Gizicka 2010: 325). Reakcja pacjenta na wiadomość o śmierci została szczegółowo opisana przez Elisabeth Kübler - Ross w książce Rozmowy o śmierci $i$ umieraniu (On Death and Dying). Autorka publikacji przedstawiła psychologiczną teorię reakcji pacjenta na wiadomość o zbliżającej się śmierci. Zdaniem amerykańskiej lekarki osoba chora terminalnie przechodzi przez „pięć kroków” wobec śmierci, zwanych inaczej etapami umierania: 1. Zaprzeczania i izolacji; 2. Gniewu; 3. Targowania się; 4. Depresji; 5. Pogodzenia się (akceptacji). Wskazane etapy nie muszą występować w ustalonej kolejności, niemniej jednak są one zawsze obecne. Por. (Kübler - Ross 1979). 
W takiej sytuacji rodzina może otrzymać jedyną pomoc od osób doświadczonych, którzy na co dzień opiekują się osobami umierającymi. Szczególnie mam na myśli lekarzy, pielęgniarki, psychologów, księży, etyków a także wolontariuszy. Niejednokrotnie pełnią oni funkcję fachowych doradców, którzy nie tylko informują o stanie zdrowia chorego, ale także uczą, że choroba bliskiej osoby nie musi być zagrożeniem, lecz wyzwaniem.

Jeśli uznamy, że każda osoba, która towarzyszy pacjentowi umierającemu jest ważnym elementem, który podtrzymuje inny, to wzajemne wsparcie, pozwala działać konstruktywnie i przez troskę o chorego, będzie można zatroszczyć się o całą rodzinę, zamieniając to co negatywne na tworzenie silnej więzi. Jak wynika z badań przeprowadzonych przez Dorotę Gizicką „u rodziców, małżonków istnieje nadmiar obowiązków, który sprawia, że nie mają dużo czasu dla siebie $(21,8 \%)$, ale przez to więcej rozmawiają ze sobą niż wcześniej (19,5\%)”. Można więc przypuszczać, że chociaż zmniejsza się ilość czasu spędzanego razem, to poprawia się jego „jakość”. Ponadto ważna jest postawa otwartej komunikacji. „Wspomagająca komunikacja rodziców/małżonków pomaga dziecku/ osobie dorosłej w jego staraniach bycia aktywnym i współpracującym podczas badań lekarskich i zabiegów, wzajemne wsparcie obojga rodziców/członków rodziny i przyjaciół w przezwyciężaniu choroby koreluje z przezwyciężeniem choroby przez samo dziecko/osobę dorosłą, następuje korelacja stanu wiedzy o chorobie poszczególnych członków rodziny z pozytywną relacją między rodzicami/małżonkami” (Buczyński 1999: 59). Postawa otwarta ma też związek z podejmowaniem rozmów na temat choroby i zagrożeń z niej wynikających. Nie można zaprzeczać faktom. Może to spowodować, że chory odwróci się od najbliższych i skieruje ku innym osobom. Ponadto w rozmowę warto też zaangażować rodzeństwo chorego. Otwarta komunikacja pozwala dzieciom na zbliżenie się do siebie, a obecność dziecka chorego w domu, zwłaszcza w fazie terminalnej daje możliwość przebywania razem z rodzeństwem oraz wspierania się nawzajem.

\section{Systemowy model opieki personelu medycznego nad osobą umierającą}

W modelu systemowym każdy kto pełni opiekę nad osobą umierającą (a szczególnie pracownicy współpracujący z oddziałami opieki paliatywnej np. lekarze, pielęgniarki, rehabilitanci, wolontariusze, pracownicy socjalni, psycholodzy, a także kapłani oraz etycy) odgrywają bardzo ważną rolę. Poprzez zapewnienie opieki medycznej, poświęcenie uwagi, troskę, okazane zainteresowanie, wszyscy spełniają oczekiwania osoby chorej. Osoba cierpiąca oraz jej potrzeby są więc w centrum uwagi. Jej wartość jest na pierwszym miejscu i nikt nie powinien tego zmienić. Tylko $\mathrm{w}$ ten sposób można uszanować godność osoby hospitalizowanej.

Nakierowanie wszelkich działań na realizację dobra osoby chorej terminalnie jest fundamentalnym założeniem opieki paliatywnej. Już słowo pallium i palliatus $\mathrm{z}$ j. łac. oznacza płaszcz, okrycie, dlatego pacjenta chroni się niczym płaszczem lub innym okryciem przed bólem i cierpieniem.

Zdaniem Światowej Organizacji Zdrowia (WHO) „opieka paliatywna jest całościową, czynną opieką nad chorymi, u których choroba nie poddaje się skutecznemu leczeniu przyczynowemu. Obejmuje ona zwalczanie bólu, innych objawów oraz opanowywanie problemów psychicznych, socjalnych i duchowych chorego. Celem opieki paliatywnej jest osiągnięcie jak najlepszej, możliwej do uzyskania jakości życia chorych i ich rodzin" (Światowa Organizacja Zdrowia 1993: 14).

W treść zadań opieki paliatywnej wpisanych jest szereg czynności, a przede wszystkim uśmierzanie bólu i kontrolowanie innych, fizycznych objawów choroby bądź umierania. U chorych z zaawansowanym procesem nowotworowym opieka paliatywna będzie realizowania nie tylko poprzez poprawę jakości życia, złagodzenie terminalnych objawów, ale także spowolnienie choroby w skutek stosowania paliatywnej 
radioterapii czy też paliatywnych operacji chirurgicznych.

Kolejnym elementem jest dążenie do realizacji potrzeb cielesnych, psychicznych, społecznych i duchowych człowieka. Jeśli wolą pacjenta jest spotkanie i rozmowa z kapłanem w celu wyspowiadania się, przyjęcia sakramentów, uporządkowania problemów duchowych, a nawet wybaczenia sobie i innym, to niezależnie od przekonań wyznaniowych zarówno pracownicy medyczni, a także członkowie rodziny powinni uszanować wartości osoby umierającej. Spełnienie woli pacjenta powinno nastąpić także wtedy, kiedy prosi, aby opieka nie była kontynuowana w szpitalu, lecz w domu - w towarzystwie osób bliskich i przyjaciół.

W definicji też zwraca się uwagę na prawo pacjenta do autonomii. Wyrażenie własnej opinii co do stosowania terapii, jej kontynuowania lub zaprzestania powinno być także brane pod uwagę przez pracowników medycznych.

Ostatnim postulatem jest otoczenie opieką nie tylko osobę umierającą, ale także jego rodzinę. Śmierć osoby bliskiej potrafi rozbić relacje między jej członkami. Należy uwzględnić fakt, że osierocone dzieci po śmierci rodzica będą cierpieć, a okres żałoby będzie trwał bardzo długo. W tej sytuacji potrzebne jest „wyciągnięcie dłoni” i zaoferowanie pomocy doświadczonego psychologa bądź księdza.

W definicji opieki paliatywnej można więc odnaleźć ważne informacje, które dają podpowiedź w jaki sposób można uszanować potrzeby osoby umierającej. Moim zdaniem, warto niektóre informacje zawarte we wskazanej definicji rozszerzyć i uzupełnić o określone przykłady. Tak więc uważam, że najważniejsze założenia, to:

a. przestrzeganie prawa do autonomii pacjenta,

b. rezygnacja z nieproporcjonalnych środków leczniczych,

c. stosowanie zasady podwójnego skutku w terapii uśmierzenia bólu.

\section{Przestrzeganie prawa do autonomii pacjenta}

Kompetentny pacjent na każdym etapie choroby może odmówić leczenia. Może również nie wyrazić zgody na terapię ratującą lub podtrzymującą życie. Jeśli chce on przedstawić własną opinię, to w tym celu istnieją stosowne dokumenty takie jak: testament dyspozycji życia (living will), prawne pełnomocnictwo do podejmowania decyzji dotyczących postępowania medycznego, opis uznawanych wartości, w których pacjent informuje o systemie afirmowanych wartości, a także oświadczenie woli oraz dokumenty dotyczące niepodejmowania resuscytacji.

Najbardziej znanym i stosowanym dokumentem jest testament życia. W nim pacjent może szczegółowo podać informacje w jakich okolicznościach życzy sobie kontynuacji leczenia, a także ma prawo ustalić warunki w jakich żąda przerwania terapii. Lekarz, po zapoznaniu się z treścią wiadomości ma również prawo szukać potwierdzenia tych informacji, upewniając się, że osoby spokrewnione z chorym znają jego wolę. Podobnie jest w przypadku dyrektywy o niepodejmowaniu resuscytacji (DNR directives), które jest oświadczeniem sporządzonym przez kompetentnego (świadomego) pacjenta. Wyrażając swój sprzeciw, pacjent nie chce w pewnych okolicznościach, (kiedy nie będzie miał realnych szans na powrót do odzyskania zdrowia), żeby został przeprowadzony zespół czynności ratunkowych (jak oddech zastępczy, masaż serca, elektroterapia, farmakoterapia) mających na celu utrzymanie lub przywrócenie transportu tlenu do tkanek co skutkowałoby przywróceniem samodzielnej czynności akcji serca i samodzielnego (lub wspomaganego) oddechu. Niepodejmowanie resuscytacji może nastąpić również z woli lekarza (DNR orders) jeśli uzna on resuscytację za procedurę medycznie daremną (nieskuteczną), albo kiedy pacjent porosi lekarza by ten spisał jego wolę.

Ostatnim z dokumentów jest oświadczenie woli. Ten rodzaj pisma ma ważne znaczenie również przy transplantacji. Informuje on lekarza, że pacjent jeszcze za 
życia wyraził świadomie zgodę, żeby po śmierci jego organy zostały ofiarowane osobie potrzebującej.

Upowszechnienie się zwyczaju spisywania oświadczeń woli sprawił, że ‘coraz więcej pacjentów z niego korzysta. W Polsce chociaż nadal nie ma regulacji prawnych dotyczących stosowania dokumentów takich jak (Oświadczenie woli, czy testament życia), to wyjątek stanowią odmowa przetoczenia krwi przez Świadków Jehowy oraz zgłoszenie w Centralnym Rejestrze Sprzeciwów (Poltransplant) odmowy w przekazaniu organów po śmierci pacjenta ${ }^{11}$.

Wymienione dokumenty pomimo swoich ujemnych stron są nadal respektowane przez lekarzy. Przede wszystkim pracownicy medyczni powołują się na ich treść, ponieważ odzwierciedlają one autonomię pacjenta, a prawo do autonomii pacjenta jest trwałym założeniem, a nawet podstawą

11 Problem, który dotyczy przetoczenia krwi u świadków Jehowy jest zarówno od strony prawnej jak i etycznej bardzo trudny do rozwiązania. Podstawę prawną, mimo że stanowi przekonanie o obowiązkach lekarza co do ochrony życia i zdrowia ludzkiego oraz leczenia i zapobiegania chorobom, a także niesienia ulgi w cierpieniu, to jeśli pacjent wyraża sprzeciw na uczestnictwo w zabiegu, bądź dysponuje oświadczeniem pro futuro, to nie powinien spotkać się z odmową przedstawiciela służby zdrowia. Widać wyraźnie, że dylemat przetoczenia krwi „spoczywa na barkach” lekarza i ma związek z funkcją, którą pełni zawodowo, czyli ponoszeniem odpowiedzialności za życie i zdrowie pacjenta, a także powstrzymywaniem się od decyzji, które mogłyby zaszkodzić choremu. Ponadto lekarz jest też zobowiązany do uszanowania prywatnych poglądów osób hospitalizowanych. Nie może więc on przystąpić do czynności medycznych nie posiadając stosownej zgody. W konsekwencji problem przetoczenia krwi u Świadków Jehowy dotyczy pogodzenia obu wartości życia i zdrowia z wartością samodecydowania. Moim zdaniem, właściwy sposób postępowania polega na zastosowania terapii z użyciem środków niekrwiopochodnych, po to, żeby uszanować prawo do światopoglądu pacjenta. (Szewczyk 2009: 297), Por. (Żaba, Świderki, Żaba, Klimberg, Przybylski 2007: 138-143) zamieszczone w Internecie: http://www.amsik.pl/archiwum/1_2007/1_07ae.pdf [dostęp: 20.10.2017]. Por. (Kodeks Etyki Lekarskiej: art.2). ważnego dokumentu jakim jest: art. 9 Konwencji o Ochronie Praw Człowieka i Godności Istoty Ludzkiej wobec Zastosowań Biologii i Medycyny ${ }^{12}$, którego treść należy respektować.

\section{Rezygnacja z nieproporcjonalnych środków leczniczych}

Następnym etapem w drodze do respektowania prawa chorego do godnej śmierci jest rezygnacja $\mathrm{z}$ nowych form terapii. W literaturze bioetycznej od lat temat ten jest związany z zagadnieniem zaprzestania leczenia i rezygnacją z terapii nieproporcjonalnych. Jest to o tyle kłopotliwe, o ile niektórzy pospiesznie wysuwają wniosek, że jeśli lekarz, rezygnuje z leczenia, bądź w ogóle nie podejmuje decyzji o zastosowaniu nowych możliwości terapeutycznych np. nie poddaje pacjenta eksperymentom, które mają na celu wypróbowanie skuteczności nowego leku, to tym samy odbiera on pacjentowi szansę na odzyskanie zdrowia. Ponadto uważa się też, że zaprzestanie leczenia jest rodzajem eutanazji biernej, utożsamianej z zabójstwem ${ }^{13}$.

Lekarze, którzy na ogół zachowują duży dystans do nowych terapii, nie chcą też ich stosować, jeśli są przekonani o ich znikomej skuteczności. Ocenę wydają na podstawie zebranych badań również dotyczących kondycji zdrowia pacjenta. Chory terminalnie, który jest w ostatnim etapie zmagań z chorobą nowotworową ma wyniszczoną odporność organizmu, dlatego zastosowanie kolejnej chemioterapii czy też operacji chirurgicznej nie tylko nie spowoduje, że

12 „Należy brać pod uwagę wcześniej wyrażone życzenia pacjenta co do interwencji medycznej, jeżeli w chwili jej przeprowadzania nie jest on w stanie wyrazić swojej woli" Por. (Konwencja: art.: 9).

13 „Odmowa przez pacjenta poddania się leczeniu nieproporcjonalnemu nie jest samobójstwem, a zastosowanie się lekarza do życia podopiecznego nie stanowi współudziału w samobójstwie, ani nie jest jakąkolwiek formą zabójstwa. Do woli chorego bezwzględnie powinna się zastosować rodzina. Akceptacja jego decyzji nie daje żadnych powodów do wyrzutów sumienia czy poczucia winy, że niewystarczająco dużo zrobiło się dla dobra najbliższego". (Szewczyk 2009: 301). 
pacjent odzyska zdrowie, ale narazi go na dodatkowe skutki uboczne (nieznośny ból, nudności oraz cierpienie). W wyniku zbytniego osłabienia odporności organizmu na skutek wdrożenia dodatkowych procedur leczenia, mogą też pojawić się nowe choroby np. bakteryjna infekcja płuc.

Uwzględniając zatem kryteria obiektywne leku oraz subiektywną ocenę brzemienia życia pacjenta, lekarz ma obowiązek patrzeć na dobro chorego i nie poddawać go eksperymentalnym badaniom, ani tym samym uporczywej terapii czy też leczenia daremnego.

Już Karta Praw Człowieka Umierającego zakłada, że pacjent ma prawo do godnej i naturalnej śmierci, a nie stosowania terapii nieproporcjonalnych, które za cenę wydłużenia okresu życia może tylko o kilka miesięcy sprawi, że człowiek umierający będzie przechodził męki i katusze.

\section{Stosowanie zasady podwójnego skutku w terapii uśmierzenia bólu}

Ostatnim z wybranych przeze mnie zagadnień jest ustosunkowanie się do terapii uśmierzenia bólu. Zdecydowana większość osób wprawdzie twierdzi, że podstawową czynnością medyczną w opiece paliatywnej jest uśmierzenie bólu osoby umierającej, niemniej jednak, jeśli zastosowane analgetyki okażą się przyczyną przyspieszenia śmierci pacjenta, to pojawiają się głosy, które zrównują ten czyn z przestępstwem (eutanazją).

Czy można ten problem wyjaśnić od strony etycznej?

Uśmierzenie bólu jest podstawową czynnością wykonywaną w ramach opieki paliatywnej. Nie można więc z niej zrezygnować, narażając pacjenta na bezużyteczne cierpienie.

Jeśli przyjmiemy założenie patocentryczne i uznamy, że cierpienie pacjenta nie jest nikomu do niczego potrzebne, to nie będziemy chcieli narażać go na niepotrzebne skutki uboczne, np. wydłużenie czasu zmagań $\mathrm{z}$ agonią (Galewicz 2010).

W medycynie podanie analgetyków jest związane z natężeniem bólu i chorobą pacjenta.
Stosuje się więc zarówno proste analgetyki jak paracetamol oraz niesteroidowe leki przeciwzapalne i słabe opioidy jak kodeina lub silne opioidy m.in. morfinę.

W przypadku użycia letalnej dawki opioidów następuje przyspieszenie śmierci pacjenta. Lekarz, który wykonuje tę czynność uważam, że nie może być oskarżony o uśmiercenie pacjenta. Powołując się na zasadę podwójnego skutku, warto zauważyć, że czyny moralne nie tylko dzielą się na dobre i złe, ale także na intencjonalne i niezamierzone. Zazwyczaj przywykliśmy oceniać postępowanie lekarzy, że względu na skutki samych działań, ale nie możemy zapomnieć o intencjach. W tym przypadku intencją lekarza była pomoc w uśmierzeniu bólu, a nie jego uśmiercenie.

Zdaniem zwolenników etyki troski, żeby to zrozumieć bardzo ważna jest edukacja tanatologiczna całego społeczeństwa, nie tylko lekarzy, pielęgniarek, ale także prawników oraz rodzin osób umierających. Lekarze nie czerpią satysfakcji ze śmierci pacjenta, dlatego w imię zasady etycznej Hipokratesa $\mathrm{Sa}$ lus aegroti suprema lex esto (dobro chorego najwyższą zasadą) chcą, żeby uniknął on niepotrzebnych cierpień.

\section{Podsumowanie}

Zrozumienie osoby umierającej, czy to poprzez otoczenie chorego troską i miłością, obecnością bliskich, przebaczeniem, pogodzeniem się ze śmiercią, a od strony medycznej uśmierzeniem bólu, oraz rezygnacją z terapii nieproporcjonalnej, kreuje postawę konstruktywną, w której to nie choroba jest najważniejsza, ale dobro osoby umierającej. Podmiotowe traktowanie człowieka nie może jedynie odnosić się do osób w pełni swych fizycznych i mentalnych sił. Trzeba mieć na uwadze fakt, że pewnego dnia każdy z nas będzie osobą starszą, schorowaną, potrzebującą opieki i troski, dlatego tak ważne jest budowanie trwałych i silnych więzi nie tylko między osobami spokrewnionymi. Nie możemy pozwolić, aby szerzyła się dyskryminacja pacjentów ze względu na wiek. W XXI w. ageizm jest jednym 
z największych zagrożeń. Osoby starsze stają się często ofiarami: niestosownych żartów, przemocy fizycznej i psychicznej, a także wydziedziczenia. Należy pamiętać, że tylko przez odnoszenie się z szacunkiem do drugiego człowieka nasza osobowość dojrzewa do pełnej odpowiedzialności moralnej.

\section{Bibliografia}

Antologia bioetyki. Poczatki życia ludzkiego, 2010, Galewicz W. (red.), Universitas, Kraków.

Buczyński F.L., 1999, Rodzina $z$ dzieckiem chorym na białaczke, Dział Wyd. Poligraficzny KUL kolportaż Lublin.

Czekajewska J., 2014, Przemiany życia rodzinnego. Studium etyczne, Wyd. Tako, Toruń.

Dz.U. $2009 \mathrm{nr} 52$ poz. $417 \mathrm{z}$ dnia 28 kwietnia 2009 r., ustawa z dnia 6 listopada 2008 r. o prawach pacjenta i Rzeczniku praw pacjenta

Gizicka D., 2010, Funkcjonowanie rodziny z dzieckiem terminalnie chorym, [w:] „Doświadczenie choroby w perspektywie badań interdyscyplinarnych", Bożena Płonka-Syroka, Michał Skrzypka, Akademia Medyczna im. Piastów Śląskich, Wrocław.

Góralczyk E., 1996, Choroba dziecka w twoim życiu, Warszawa.

Instr. Dignitas personae dotyczaca niektórych problemów bioetycznych, 2008, Kongregacja Nauki Wiary, Wydawnictwo św. Stanisława BM, Kraków. Jan Paweł II, 1989, Adhortacja apostolska Christifideles Laici, Pallottinum, Kraków.

Jan Paweł II, 1995, Encyklika Evangelium vitae, Wydaw. M., Kraków.

Kant I., 1984, Uzasadnienie metafizyki moralności, PWN, Warszawa.

King M. L., 1977, Strength to Love, Fortress Press.
Kodeks Etyki Lekarskiej, obwieszczenie nr 1/o4/ IV Prezesa Naczelnej Rady Lekarskiej z dnia 2 stycznia $2004 \mathrm{r}$.

Konwencja o Ochronie Praw Człowieka i Godności Istoty Ludzkiej wobec Zastosowań Biologii i Medycyny z dnia 19 listopada $1996 \mathrm{r}$.

Korczak J., 2012, Pamiętnik $i$ inne pisma $z$ getta, W.A.B, Warszawa.

Kübler - Ross E., 1979, Rozmowy o śmierci i umieraniu, Media Rodzina, Poznań.

Leczenie bólu w chorobach nowotworowych i opieka paliatywna, 1993, Światowa Organizacja Zdrowia, Fundacja Pomoc Krakowskiemu Hospicjum, Kraków.

Leone S., 20oo, Śmiertelnie chory, Wydaw. WAM, Warszawa.

Locke J., 2015, Dwa traktaty o rzadzie, Aletheia, Warszawa.

Stownik teologii biblijnej, 1990, Dufour X.L. (red.), Pallotinum, Poznań.

Szewczyk K., 2009, Biologia. Medycyna na granicach życia, PWN, Warszawa.

Tomasz z Akwinu, 1960, Suma teologiczna., Veritas, Londyn.

Wohlleben P., 2017, Duchowe życie zwierzat. Wyd. Otwarte, Kraków.

Żaba C., Świderki P., Żaba Z., Klimberg A., Z. Przybylski, 2007, Zgoda Świadków Jehowy na leczenie preparatami krwi-aspekty prawne i etyczne, sprawozdanie z konferencji, Archiwum Medycyny Sądowej i Kryminologii, Poznań.

(Web-o1) https://www.youtube.com/watch?v=BrCpogue-v8\&t=43s [dostęp: 25.10 .2017 ] 


\title{
The dignity of a person dying of moral obligation in medicine
}

\begin{abstract}
In the Christian tradition, the concept of 'dignity' derives from natural law. According to St. Thomas Aquinas, every human being preserves inherent dignity throughout life because it comes from God. In line with this thought is the view that the gift of dignity cannot be taken away. Even various forms of aggression and hatred are not capable of destroying humanity; in other words, they cannot deprive man of this most precious value.

In the interest of spiritual development, philosophers and theologians urge adherence to moral standards. Actions based on an ethical foundation teach responsibility and thus are important to respect.

This article on human dignity explores these ideas through the example of medical care for chronically and terminally ill patients. I not only focus on palliative care but also explain how to care for a dying person while respecting his or her rights as a patient, especially the right to a decent and peaceful death.
\end{abstract}

\section{Keywords}

dignity, palliative care, worthy of death, tanatological education, pain relief, cancer disease. 